\title{
18 The National Theatre, London, as a theatrical/architectural object of fan imagination
}

\author{
Matt Hills
}

\section{Introduction}

Stijn Reijnders has argued that "memory seems to play an important part in the way in which places of the imagination are experienced. In other words, one can identify a certain reciprocity between memory and imagination" (2011: 113). This chapter builds on such a recognition by focusing on the "mnemonic imagination" (Keightley \& Pickering, 2012) within place-making affects. At the same time, I am responding to the question of whether it is "possible to be a fan of a destination?" (Linden \& Linden, 2017: 110). As Rebecca Williams (2018: 104) has recently argued, we need a greater understanding of

what places can do to visitors who may not bring particular media or fan-specific imaginative expectations with them and yet may respond strongly to a particular place. . . . What confluence of affective, emotional and experiential elements may cause them to become fans of that site ...?

By focusing on the Royal National Theatre on the South Bank of London usually referred to as the "National Theatre" or the "NT" - I am deliberately taking a case study which multiplies some of these questions, since the NT has acted as the site for both theatre fandom (Hills, 2017) and what has been termed "architectural enthusiasm" (Craggs et al., 2013, 2016). Indeed, the National Theatre has been marked by a related doubling throughout its history (having opened in 1976 after a much-delayed construction process). For, as Daniel Rosenthal (2013: 845) observes in The National Theatre Story, it represents "what [playwright] Tom Stoppard termed coexistent institutions: 'One was the ideal of a national theatre; the other was the building"'. As such, it has also given rise to two "co-existent" forms of fandom and imaginative place-making, one focused on its theatrical status, and one focused on its distinctive brutalist architecture - "brutalism" coming from the French for "raw concrete", or béton brut, which makes up much of architect Denys Lasdun's stark building. However, these co-existent responses to the NT should not be seen as installing a binary of (theatrical) 
textuality versus (architectural) materiality - as Cornel Sandvoss (2014: 116) has noted in his work on fandoms articulated with locations, "places, and in particular places of pleasure and affect, are also always texts". This is certainly true for the NT's monumental public architecture, which is aligned with artistic/consumerist branding and mediated in a range of ways, not just through the "architectural gaze" of photography (Aigner, 2016: 190) but also via the consumption of souvenirs and merchandise (Garduño Freeman, 2018: 133, 136; Grindrod, 2018: 139). And, of course, the NT's theatrical and architectural fan imaginings also intersect: as a building located in a specific part of London and situated by the bank of the River Thames, it can operate as a "pilgrimage theatre" for visitors (Carlson, 2003: 157) and as an example of "architourism" (Ockman \& Frausto, 2005), interweaving architectural materiality with theatregoing recollections. As a site that is celebrated by "brutalist fans" (Grindrod, 2018: 139), the cultural meanings of the NT - especially as a publicly funded project pre-dating the culturalpolitical normalizations of neoliberalism - can also be textually mapped onto the building's enduring physicality.

Having accepted that both text/matter and theatre/architecture slip across each other, I will nonetheless structure my analysis in terms of first exploring theatre fandom before then turning to architectural enthusiasm. This is because the two practices often occur in different cultural spaces (e.g. forums such as Theatreboard) and through different social organizations (e.g. the Twentieth Century Society). Although it would be experientially possible for one person to combine and integrate theatre and architecture fandom, nevertheless the communal expressions and articulations of these fandoms tend to be sequestered and hence more singularly, artificially bounded - at the Theatreboard forum, for instance, there are subforums to share one's interest in specific plays (usually those about to be staged) and theatrical performers, but there is no sustained focus on theatres in terms of their architectural design. Similarly, in the Twentieth Century Society's magazine, $\mathrm{C} 20$, there is a concentration on buildings and their design, but even where these buildings may be theatres, there is no significant focus on their dramatic output. In each case, the fandom is enacted as relatively bounded and concentrated, its proper objects ("material" theatres; the art of theatrical productions) being implicitly defined and centred for other members of the fan community. Curiously, it is perhaps the National Theatre Shop which places architecture and theatre fandom most visibly side by side, each being rendered as a contiguous consumerist target market and thus represented via items shared (Kershaw, 1994: 174).

I will begin by introducing the "mnemonic imagination" (Keightley \& Pickering, 2012) in relation to theatre fandom. This concept refuses to view memory merely as a "trace", against which imaginative processes can be viewed as somehow more creative or productive, arguing instead for the need to theorize memory as intertwined with imagination, without becoming somehow false. The mnemonic imagination, for Keightley and 
Pickering, is what enables the imaginative leap of connecting experiences, hence underpinning forms of ongoing self-narrative. It can therefore give us a way of newly understanding the repeated experiences (return visits; mediated encounters and "being there") which become threaded together in fans' narratives of self, and their associated attachments to places (Waysdorf \& Reijnders, 2018: 3). Critic Matt Trueman (2016) has argued that

It's very hard to be a fan of a building. ... You can get to know an artist or a company, in a way you can't a venue. Their personality shines through [in] their shows. . . . Buildings shift with each show they host. They might have a manifesto, a set of values, maybe even something like personality, but it's abstract and detached. It's not tied to individuals.

But if this is so, how does the National Theatre let "us become fans" (ibid)? And following the "mnemonic imagination", how might this be an imaginative process, as much as one based on fan memory?

\section{Theatre fandom: ventriloquized and materialized}

If media tourism, or visiting a pilgrimage theatre, involves negotiating "between a realized imagination and an imagined reality" (Reijnders, 2011: 114), then we surely need to address how this sifting occurs. As Reijnders reminds us, it is precisely "[b]ecause imaginations and realities are interwoven, [that] people feel the need to unravel them" (ibid: 15). And in terms of repeated theatregoing by "theatre mavens" (Bennett, 2005: 409), we cannot split this dialectic of imagination and reality into buildings merely treated as the "real", and plays/performances presumed to proffer the "imagined". For, as Marvin Carlson (2003: 143) has pointed out, contra Matt Trueman's notion that buildings shift with every show:

[E]lements of theatre ... tend to be reinforced by their association with specific physical buildings. Certain dramatists, certain companies, certain actors, certain designers, often remain for years or even decades at a particular location, and so the audience memories of the previous work of those various theatre artists are reinforced by the fact that much or all of that previous work was experienced in the same physical surroundings.

There is hence a "ghosting" or layering of theatre fans' memories over each new visit to a theatre building, not only in terms of previous productions seen there but also "where ... the memories ... of that part of the city help to provide a reception context for any performance seen" (ibid: 140).

Bringing together the insights of Reijnders and Carlson means, in turn, that memory and imagination are necessarily articulated here; theatre fans engage with particular theatres as places of the imagination simultaneously through memory traces, narratives of producers/performers, geocultural 
associations, and aesthetic experiences of imagined worlds. Keightley and Pickering's (2012) notion of the "mnemonic imagination" therefore offers a valuable theoretical resource, one which emphasizes how memory and imagination are intertwined (ibid: 3 ) and thus how memory can itself be creatively narrated (ibid: 6). As they have argued,

It is through the mnemonic imagination that our engagements with the past move through a series of interactive dualities: . . . the interplay between experience and expectation, memory and possibility; the relations between lived first-hand experience and mediated ... second-hand experience. Exploring the movement between these dualities is crucial.

(ibid: 7)

Keightley and Pickering emphasize how the mnemonic imagination "makes possible the grasping together of the past, present and future in ways that create new meaning" (2012: 63), since it allows for the past and the present to be sifted, contrasted, and narrated within ongoing self-identity, affirming the theatre fan's self-narrative as someone who repeatedly visits particular venues and recalls that history (through first-hand and mediated experience) as meaningful in the present.

As Sandvoss (2014: 134) notes, such memories - products, I am arguing, of the mnemonic imagination - provide "important bookmarks ... in fans' reflexive constructions of personal narratives ... that mark a means through which ... enthusiasm becomes a narrative resource in fans' life courses". At the same time, such "memories foster a sense of attachment and security ... [to] a place where fans . . belong - a form of emotional home" (ibid). The metaphor used in the Handbook of Imagination and Culture for this is actually one of "trails of the imagination" (Glaveanu \& Zittoun, 2018: 360), where the imagination is culturally channelled into iterated "beaten tracks" (media franchises, brands, major venues, etc.) and personally "familiar paths" (ibid: 361) within which places such as the National Theatre can become points of attachment and Heimat experiences for fans/enthusiasts. This very much resonates with well-established work on place and belonging, for example, by Yi-Fu Tuan (1977: 82) and David Seamon (1979: 57), which argues for the importance of repeated visits and familiarity in relation to feelings of place-oriented attachment. Heightened and especially "intense" experience (Tuan, 1977: 185) can also provoke new "trails of the imagination", however - this could be a first experience of monumental architecture such as the NT or a first experience of (located) theatrical artistry. Here, though, it is being suggested that repeated or habitual experiences may also be repeatedly imagined and thus connected and cathected into the groove of fans' self-narrative.

Such "bookmark" memories or "familiar path" of recursive, revisited imaginings are richly evident in the National Theatre programme for its 50th anniversary event (Haill, 2013). Here, NT staff, playwrights, and politicians 
were invited to commemorate the theatre's half-century (extending back to the National Theatre company's beginning in 1963, then based at the Old Vic). Contributors tended to affirm personal early memories and/or memories of taking their children to the National for the first time:

In my teens in the late 1970s I fell in love with the National Theatre. I loved the building, the plays, the cafes and the bookshop. It seemed to me the most glamorous and civilized place on earth. It became my hangout. The place I went to read, watch, listen, write, learn and dream. ... . I am as thrilled as ever to be able to enter via the Stage Door. I met my wife Debra fifty yards from that door. When our first child became of play-going age we took him, of course, to the NT. . . Thank you NT for the life you have given me.

(Marber in Haill, 2013: 17; see also Miller in Haill, 2013: 39)

There is a sense of passing the NT on to offspring as a sort of parental gift, whilst this also acts, in sociological terms, not only as part of a self-narrative of home/belonging (Waysdorf \& Reijnders, 2018) but also as the intergenerational transmission of cultural capital. This notion of belonging at the National is also present in playwright David Hare's account, Hare having been extensively associated with the National (Billington, 2007: 327). He recalls that when "we moved into the South Bank, ... it was so huge that ... I would run into friends I hadn't seen for years, but who turned out to be working somewhere in the building" (Haill, 2013: 23).

John Grindrod interviewed National Theatre staff in his study Concretopia, and there was a similar sense of blending past and present through the mnemonic imagination. These staff members again recall early experiences of the NT - crucially, before they worked there professionally - cementing self-narratives of "familiar paths":

Paul, who had joined the lighting department in 1982, had similarly warm feelings about the building from the start. "I always loved the building", he told me. "I live in central London, just down the river, and I watched it being built. I used to come down here and get excited, and I always thought it was a wonderful space, a wonderful structure. Always liked it. Always fascinated by it."

(Grindrod, 2014: 420)

Though it can be argued that "fans ... are more likely to share their experiences and thus contribute to the wider 'story' of a destination" (Linden \& Linden, 2017: 113), these are "theatre professionals-as-fans" (Tulloch, 2018: 426), meaning that the expressions of NT fandom which tend to have been officially recorded do not hail more broadly from outside theatre's professional world (Haill, 2013). Those who "reside" at the NT, if you like, are valued above tourist or pilgrim fan audiences, who remain somehow an 
"alien culture" (Bennett, 2005: 409), spoken for by staff: “The NT rewards repeated visits.... It grows on you. Once, in a meeting of NT technical staff, [a] theatre consultant ... asked how many loved the building. A forest of hands went up" (Dillon, 2015: 85). Those within the professional theatre field act as a substitute voice for external fans, providing a kind of ventriloquized fandom that can more securely discursively anchor the value of the NT's activities. The aberration or unexpectedness of "outsider" fan voices is sometimes acknowledged, as when former NT Artistic Director Nick Hytner recounts how people would approach him to say how much they loved the NT before then mentioning the lack of queues for the ladies' toilets or "exceptional" meatballs in the Terrace restaurant. Hytner (2017: 273-274) acknowledges that "I learned to be as happy to hear about interval activity ... as I was to hear about the play", indicating that when fans are not ventriloquized via professional accounts, then they do not stick to aesthetic discourses of theatrical appreciation.

Seeking testimonies from ordinary fans of the NT would also risk exposing just how little they might represent "the nation" - whatever that could mean in terms of multiple constructs - but it nevertheless seems culturally safer to leave the nation, precisely as an imagined community, very firmly imagined behind the figures of NT staff, playwrights and actors, allowing the NT to "maintain the illusion of its reconstruction of a ... public sphere" (Jones, 2007: 128). As Ross Garner has noted, limiting "discussion of anniversaries and affect to institutionally controlled examples results in fans' affective responses becoming marginalized" (2018: 67).

For the ordinary, non-professional theatre fans who gather at Theatreboard (theatreboard.co.uk), a forum formerly linked to the publication What's On Stage but run independently since 2016 by "a group of dedicated fans" (MyTheatreMates, 2016), the NT is discussed in relation to its specific productions, and its new seasons are also communally pored over. Fan comments in "New Season" threads display the mnemonic imagination's "interactive dualities" of experience and expectation, drawing on previous encounters with the National and positioning theatrical knowledge as bound up with consumerist expectations. Here, the NT is represented primarily as an organization that forum members want to interact with as well-served consumers; NT website crashes are reported on, and posters share their adventures in terms of trying to secure tickets, as well as sharing tips on when/how to get cheap but decent seats, sometimes at the front of the stalls. The NT as an architectural space is backgrounded, with the emphasis falling on how well run (or not) online ticket sales are, as well as on debates surrounding the composition of each new season immediately it's announced.

Non-professionalized theatre fandom has been othered as excessively consumerist in versions of theatre studies (though this situation is changing as work on theatre fandom continues to develop). For example, Baz Kershaw (1994: 174) laments how "wearing . . . a National Theatre peaked cap may be even more culturally charged than an evening in the stalls watching the 
show", with consumption supposedly being substituted for authentic theatrical experience. Set against this, Caroline Heim's (2016: 133) audience studies' work on "mainstream theatre", based on interviews with theatregoers, stresses how the "theatrical programme, more than any other souvenir, stirs the memory of the event. . . Some audience members cherish and almost deify their programmes. ... For some ..., the programme subsumes all the memories of the suspended moments of the production ... and becomes 'a time capsule to capture a special moment in time"”. And even where fans are not attending the National Theatre building on the South Bank, instead watching productions beamed live to a local cinema as part of the "NT Live" scheme, a "physical reminder of the event in the form of a programme was desired by 22 per cent of respondents... . The importance of physical items is also evident in the 14 per cent who said they would consider buying NT Live official merchandise after watching the broadcast" (Abbott \& Read, 2017: 181). Retail is thus a normalized part of contemporary theatre fans' expectations (Heim, 2016: 132), with souvenirs such as programmes acting as tokens of cultural capital that "place ... the work, the production, and the audience member into a nexus of ... cultural significance. The program can act as a guarantee of the cultural experience, and can help to authenticate it" (Atkinson, 2006: 155), akin to other (media) tourist memorabilia.

The programme is thus a marker of having been there, providing "materialized traces of the imagination ('souvenirs from the road')" (Glaveanu \& Zittoun, 2018: 361). But more than that, it also iterates the sense of attachment to a venue such as the NT, aiding the mnemonic imagination in stitching together memories, present affective relationships to the theatre-as-location, and a fannish self-narrative anticipating future theatrical productions (or revivals) yet to be experienced. Collecting programmes can also interweave biographical self-narrative with the shared historical narrative of a theatre. Fans can memorialize attending the NT during the eras of artistic directors or in relation to different directors' "brands" (Mermikides, 2013) and playwrights' careers: "Many of the National's most acclaimed shows have hinged on pairings who appear as recurring characters in The National Theatre Story: Peter Shaffer and John Dexter; Harold Pinter and Peter Hall; David Hare and Richard Eyre; Tom Stoppard and Trevor Nunn; Alan Bennett and Nicholas Hytner" (Rosenthal, 2013: xii). To date, the NT has had only six artistic directors since its formation in 1963 (all men); this lineage provides a way of readily narrating different historical moments. In addition, the NT's artistic directors have tended to publish their recollections of leading the institution (e.g. Hytner, 2017), and these have been supplemented by the memoirs of leading directors and playwrights (e.g. Blakemore, 2013; Hare, 2015). As a result, the NT's less formal public documentation proffers a series of not always on-brand anecdotes, differing in tone from published recollections linked to brand anniversaries such as Britain's Royal National Theatre: The First 25 Years (Goodwin, 1988) or National Theatre: 50 Years on Stage (Haill, 2013), as well as the institution's "authorised biography" (Rosenthal, 2013: xiii). 
Fans' programme-buying and souvenir consumption is therefore one way for the mnemonic imagination "to connect personal and public remembering ..., with each being implicated in the other. The work of the mnemonic imagination produces the synthesis of our first-hand experience with . . . culturally mediated second-hand experience" (Keightley \& Pickering, 2012: 199). However, as I have noted, it is not only via theatre fandom that the National Theatre becomes an object of (located) fan imagination, for it also has a dedicated following of brutalism fans, for whom its building - and architect Denys Lasdun - are more central to processes of the mnemonic imagination than specific theatre productions, directors, and playwrights. I will conclude by considering this second aspect of the NT's "co-existent" doubling (Rosenthal, 2013: 845).

\section{Architectural enthusiasm: publicized and merchandized}

The rise of Web 2.0 has moved an array of fan practices into the mainstream of cultural participation. The concept of participatory culture - initially discussed by Jenkins as an aspect of fan communities (1992) - has now been used to analyse post-show theatre engagement (Conner, 2013,2016) and interpretive communities' interactions with "iconic" architecture (Aigner, 2016; Garduño Freeman, 2018). Taking the Sydney Opera House as her case study of an architectural icon, Garduño Freeman argues that tourists and visitors "contribute to the building's representation in culture" (2018: 78 ) by sharing their photographs, videos, blogs, and material productivity. Although we might assume that participatory culture - communities producing and sharing their own media texts - democratizes the "official" mediation of architecture, Anita Aigner demonstrates that this is not always the case. Even participatory media shared online can replay the dominant cultural-industrial "architectural gaze" which

presents a building as an autonomous object viewed for its own sake. It does not show the use . . . of the object, . . . but instead . . captures the object from its best side. . . . It is characteristic for . . . [this] legitimate imaging mode, especially as regards exterior shots, that the objects are shown in full size and without much environment. ... This artefact-centred image type also assigns ... recipients a position: one of a spectator distanced and separated from the object, like a visitor to a museum opposite an exhibit.

(Aigner, 2016: 190)

As well as sharing this "authorised heritage discourse" (ibid: 183), what has been termed the "architectural enthusiasm" of organizations such as the UK's Twentieth Century Society (Craggs et al., 2013) also intersects with official governmental practices, as the Society is involved in the conservation of valued architecture. Indeed, as Craggs et al. (2016) have shown, 
architectural enthusiasts have tended to discursively police their own emotional, fannish investments in architecture by splitting communal activities into education/socializing, which can be passionate, and conservation or campaigning, which are instead very much presented as professional and rational (ibid: 1). Associations with "fandom, obsession, geekiness, or amateurism" are therefore denied by members of the Twentieth Century Society when they are involved in conservation work (ibid: 2), as "it is not always helpful to be seen as the "anoraks of concrete architecture"” (ibid: 6).

Enthusiasts have been categorized as distinct from fans on the basis that media fans focus their attention directly on media texts, whereas enthusiasts are interested in a material hobby which then leads to specific media consumption (Abercrombie \& Longhurst, 1998: 148-150). However, this binary has been relaxed in subsequent scholarship, with Longhurst (2007: 104) using "enthusing to capture the idea of some degree of investment in forms of culture be they directly media related or not". Drawing on this latter sense, architectural enthusiasm as defined by Craggs et al. (2013) - like the participatory cultures identified by Aigner (2016) and Garduño Freeman (2018) - can be thought of as a type of fandom, making sense of Grindrod's (2018: 139) description of "brutalist fans".

However, I want to suggest that the National Theatre is not so much an "icon" but rather an architectural monument that is valued by its concrete devotees. Sklair (2017) has suggested in The Icon Project that contemporary iconic architecture operates within a neoliberal framework, promoting consumption and reinforcing the dominant power of a transnational capitalist class. Sklair defines "monumentality" as belonging to an older era in the "public expression of architectural representation", with iconicity replacing this as a central discourse. The result is that "architectural iconicity has been socially produced by the corporate fraction of the transnational capitalist class in architecture and has begun to replace monumentality as a marker of the global hegemony of the capitalist class" (ibid: 53-54). Iconic architecture is usually privately funded, typically acting as a component of place-branding within the experience economy (Klingmann, 2010; Lonsway, 2009).

The National Theatre is a product of 1960 s and 1970 s UK politics, though, having opened in 1976. Architecturally, it belongs just before our intensified neoliberal era where such "[1]eft modernisms of the 20th century continue to be useful... [as] a potential index of ideas ... [that] can still offer a sense of possibility which decades of being told 'There is No Alternative' has almost beaten out of us" (Hatherley, 2008: 13). The National Theatre, as befitting its status, was designed as monumental public architecture rather than as a privatized consumer-cultural "icon". It was part of a "last push to create exciting and experimental public spaces, before responsibility for these kinds of projects shifted decisively away from public and into private hands" (Grindrod, 2014: 403). Its architect Denys Lasdun conceptualized the NT as a space that was "open" to the city and the public, comparing flows of audiences in and out of auditoria to the adjacent River Thames (Dillon, 2015:36, 
45). Lasdun also intensely valorized the NT's public spaces - foyers, walkways, and terraces - as a kind of "fourth auditorium" alongside the building's three theatre spaces (ibid: 45). Indeed, this "fourth theatre" notion (Jones, 2007: 126 ) is repeatedly emphasized in official NT publications (see also Goodwin, 1988: 99), working as an ongoing narrative legitimation of the theatre's public and "national" status. Such is the prevalence of this authorized NT discourse that the Open House London 2019 event even included a talk on the topic of "Social Spaces at the National Theatre" (Open House London, 2019).

This dominant discourse of the NT's "public" architecture, where in-between spaces of transit inside the building are generously proportioned and where interior and exterior are demarcated in "open" ways (Carlson, 1989: 161162 ) - even more so after the National's restoration project led by architects Haworth Tompkins (Grindrod, 2018: 125, 127) - vehemently positions the NT against London's more recent architectural icons (Tompkins \& Todd, 2007: 3-4). And this publicizing discursive practice - performing the NT as a resolutely public space even as it is branded and de facto commercialized in terms of having to justify its public subsidy (Kershaw, 1994: 168) - is frequently recapped in the accounts of architecture enthusiasts. Grindrod (2014: 403) says of the Barbican and the National Theatre that "[s]ince my teenage years I've spent so many hours hanging around in their concrete foyers and balconies, theatres and bars. ... To me they are ... comfortable, welcoming . . . and entirely life-enhancing”. Barnabas Calder (2016: 326) produces a similar self-narrative in Raw Concrete: The Beauty of Brutalism when he observes of the NT that there

is abundant unprogrammed space for theatregoers to mill around, passers-by to drop in ... or have a sit-down ... or any other function people might choose for what amounted to free, warm, indoor space. As a teenager without much cash I was one of countless beneficiaries, over the decades, of a place where I could read for hours, wait for or talk to friends, or just watch the world go by without having to buy and force down pints of tea or coffee.

Reminiscent of the NT regulars quoted by Nick Hytner (2017: 273-274), who appreciated the facilities in the interval as much as the plays being staged, and resembling NT staff accounts of loving to spend time in the building before they worked there (Grindrod, 2014: 420), this publicizing fandom values the NT not just for its spectacular brutalism which underpins the "architecture geek's pleasurable game" of appreciation (Calder, 2016: 273) but also for its unprogrammed interior public spaces construed as "minimally consumerist" (Sklair, 2017: 226). The mnemonic imagination at work here is one which moves through a specific duality: past and present are stitched together via an interplay between public and private, given that the current incarnation of the NT is significantly commodified, both 
through its construction as a brand (extended via NT Live) and through its merchandising not just of play texts, programmes, and posters etc, but also brutalism and the building itself.

Although the NT Shop caters to both theatre and architecture fandoms, it typically does so through distinct commodities, hence recognizing the sequestered expression of these focused interests, I would argue. For theatre fans, there is merchandise focused on playwrights, plays, and the experience of theatre's art world; this takes generic form via posters, prints, and badges. And for architecture fans, there are ranges of merchandise which instead very much emphasize the National's materiality and construction - its concrete design and brutalist identity. For example, a souvenir "architecture model" of the National can be purchased via its shop (National Theatre, n.d.), and as Grindrod (2018: 138-139) has observed, brutalism has been subjected to considerable merchandising, including paper cut-out models of the National and even a Brutalist London Map which "is designed to affirm the value of these buildings" (Billings, 2015: np.).

Like souvenirs of the Sydney Opera House, albeit less rampantly diversified across product types, the architectural and cut-out models of the NT "mediate experiences of the building. ... [S] ouvenirs invert the 'real' scale between the tourist and the building ... [enabling] people to experience the building as a whole" (Garduño Freeman, 2018: 136) and thereby enabling an experience of symbolic imagined ownership. The NT can sit, as a model, on my office desk or on my coffee table at home, rendered as a materialization of trails of imagination just like a theatre programme or a peaked cap. And although it may be true that "brutalism seen through a lens - be it books, photos, products or social media - is no substitute for experiencing the real thing ... [which] will live with you afterwards in indefinable ways" (Grindrod, 2018: 139), what remains significant is the different type of experience that an NT model or a Lasdun-oriented souvenir such as Patrick Dillon's (2015) book Concrete Reality: Denys Lasdun and the National Theatre can confer. By consuming architecture in this way, its fans are also performing their attachment to the NT as a building and a place, imaginatively transferring it from public space to privatized (domestic/work) domains of self-identity. The emotional home of the physical NT is, in this sense, not just revisited literally and imaginatively by its fans - it is also symbolically incorporated into people's actual homes and thus rendered meta-habitual, if you like, as a mode of "fan homecoming" which can be simultaneously ordinary, everyday, and extraordinary through the mediation of commemorative souvenirs and models (Waysdorf \& Reijnders, 2018: 3).

Fans hence enact a mnemonic imagination that bridges their first-hand and second-hand experiences of visiting the National and consuming mediated images of it, not just materializing memories of their visits but also literalizing the metaphorical Heimat of the place (Sandvoss, 2014: 134-135) by domesticating merchandized maquettes. Of course, it is in the interests of the National Theatre to facilitate this interiorization of its brand and its public building. 
Within a consumer-cultural, neoliberal context, this is one way (like the transferred cultural capital handed down from parents to socialized, theatregoing children) that the institution can seek to cement its future, hoping to be merchandized into people's self-narratives and self-identities as fans. Whereas Kershaw (1994: 174) viewed this consumerism as inimical to "authentic" theatre and performance, it might now be interpreted - within a mixed economy of public/private UK theatre funding - as one support, however problematic, to the National Theatre's centrality within the theatre world. Through the fan imagination, spectators can become symbolic "owners" of the NT, just as other parts of the institution's practice may invert this by commodifying experiences of theatrical and symbolic "ownership" (see Deeney, 2007: 341 on the NT's "Connections" programme for young people).

In this chapter, I've argued for the importance of considering an underexplored aspect of fandom - how theatrical venues/buildings such as the National Theatre on London's South Bank can act as places attracting their own modes of fandom. I've suggested that NT staff and celebrated theatre professionals become fan stand-ins in terms of legitimating the theatre's activities, ventriloquizing the attachments and engagements of "ordinary" theatre fans. And I've suggested that architecture enthusiasts tend to enact a publicizing stance on the value of Lasdun's building, positioning its weathered permanence (Klingmann, 2010: 51; Marini, 2013) as a pre-neoliberal and implicit rebuke to the increasingly commercialized, branded theatre culture of today. At the same time, both theatre fans and architecture enthusiasts work to locate imagination by consuming materializations of memory in the form of theatre programmes, architectural models, and so on. These forms of "fan homecoming" (Waysdorf \& Reijnders, 2018) therefore tend to combine repeated visits, rather than one-off pilgrimages, with symbolic incorporation into fans' actual homes. And this indicates, following Reijnders (2011), that we need a greater focus on fan memory as creatively linked to imagination via the "mnemonic imagination" (Keightley \& Pickering, 2012) - as well as recognizing that theatre and architectural fandoms can be relatively distinct interpretive communities, not always meeting up in the contemporary experience economy. The cultural and social value of the National Theatre are not just doubled or co-existent here but also over-determined. Although work on screen/media tourism has been productively in dialogue with work on media fandom for quite some time, I have argued that spatial forms of fandom which are less clearly or directly linked to mass media (Cavicchi, 2014: 53), such as theatre fandom and architectural enthusiasm, can also profitably be analysed in relation to places of the imagination.

\section{Bibliography}

Abbott, D. \& Read, C. (2017). Paradocumentation and NT live's 'CumberHamlet'. In: T. Sant (ed.), Documenting performance: The context \& processes of digital curation and archiving, pp. 165-187. London: Bloomsbury. 
Abercrombie, N. \& Longhurst, B. (1998). Audiences: A sociological theory of performance and imagination. London: Sage.

Aigner, A. (2016). Heritage-making 'from below': The politics of exhibiting architectural heritage on the Internet: A case study. International Journal of Heritage Studies 22(3): 181-199.

Atkinson, P. (2006). Everyday arias: An operatic ethnography. Lanham: AltaMira Press.

Barker, M. (2013). Live to your local cinema: The remarkable rise of livecasting. Houndmills and New York: Palgrave Macmillan.

Bennett, S. (2005). Theatre/tourism. Theatre Journal 57(3): 407-428.

Billings, H. (2015). Introduction to brutalism. In: H. Billings (ed.), Brutalist London Map. London: Blue Crow Media.

Billington, M. (2007). State of the nation: British theatre since 1945. London: Faber and Faber.

Blakemore, M. (2013). Stage blood: Five tempestuous years in the early life of the National Theatre. London: Faber and Faber.

Bucknell, J. \& Sedgman, K. (2017). Documenting audience experience: Social media as lively stratification. In: T. Sant (ed.), Documenting performance: The context \& processes of digital curation and archiving, pp. 113-130. London: Bloomsbury.

Calder, B. (2016). Raw concrete: The beauty of brutalism. London: Penguin.

Carlson, M. (1989). Places of performance: The semiotics of theatre architecture. Ithaca: Cornell University Press.

Carlson, M. (2003). The haunted stage: The theatre as memory machine. Ann Arbor: University of Michigan Press.

Cavicchi, D. (2014). Fandom before 'fan': Shaping the history of enthusiastic audiences. Reception: Texts, Readers, Audiences, History 6(1): 52-72.

Conner, L. (2013). Audience engagement and the role of arts talk in the digital era. New York: Palgrave Macmillan.

Conner, L. (2016, July 13) Taking back the arts: 21st century audiences, participatory culture and the end of passive spectatorship. L'Ordinaire des Amériques 220. Retrieved from http://orda.revues.org/2773 (20-08-2019).

Craggs, R., Geoghegan, H. \& Neate, H. (2013). Architectural enthusiasm: Visiting buildings with the twentieth century society. Environment and Planning D: Society and Space 31: 879-896.

Craggs, R., Geoghegan, H. \& Neate, H. (2016). Managing enthusiasm: Between 'extremist' volunteers and 'rational' professional practices in architectural conservation. Geoforum 74: 1-8.

Deeney, J.F. (2007). National causes/moral clauses? The National Theatre, young people and citizenship. Research in Drama Education 12(3): 331-344.

Dillon, P. (2015). Concrete reality: Denys Lasdun and the National Theatre. London: National Theatre Publishing.

Garduño Freeman, C. (2018). Participatory culture and the social value of an architectural icon: Sydney Opera House. London: Routledge.

Garner, R. (2018). Affective textualities, generalizations and focalizations: Fan reactions to Twin Peaks's 2014 paratextual return. Journal of Fandom Studies 6(1): 63-80.

Glaveanu, V.P. \& Zittoun, T. (2018). The future of imagination in sociocultural research. In: T. Zittoun \& V.P. Glaveanu (eds.), Handbook of imagination and culture, pp. 347-367. Oxford: Oxford University Press.

Goodwin, T. (1988). Britain's Royal National Theatre: The first 25 years. London: National Theatre/Nick Hern Books. 


\section{Matt Hills}

Grindrod, J. (2014). Concretopia: A journey around the rebuilding of postwar Britain. Brecon: Old Street Publishing.

Grindrod, J. (2018). How to love brutalism. London: Batsford.

Hadley, B. (2017). Theatre, social media, and meaning making. Cham: Palgrave Macmillan.

Haill, L. (ed.). (2013). National Theatre: 50 years on stage. London: National Theatre.

Hare, D. (2015). The blue touch paper: A memoir. London: Faber and Faber.

Hatherley, O. (2008). Militant modernism. Hampshire: Zero Books.

Heim, C. (2016). Audience as performer: The changing role of theatre audiences in the twenty-first century. London: Routledge.

Hills, M. (2017). Popular theatre and its 'invisible' fans: Fandom as external/internal to the theatrical field. LiLi: Zeitschrift für Literaturwissenschaft und Linguistik (online). DOI:10.1007/s41244-017-0074-2.

Hytner, N. (2017). Balancing acts: Behind the scenes at the National Theatre. London: Jonathan Cape.

Jenkins, H. (1992). Textual poachers. London: Routledge.

Jones, A. (2007). National theatres in context. Cardiff: University of Wales Press.

Keightley, E. \& Pickering, M. (2012). The mnemonic imagination: Remembering as creative practice. New York: Palgrave Macmillan.

Kershaw, B. (1994). Framing the audience for theatre. In: R. Keat, N. Whiteley \& N. Abercrombie (eds.), The authority of the consumer, pp. 166-186. London: Routledge.

Klingmann, A. (2010). Brandscapes: Architecture in the experience economy. Cambridge: MIT Press.

Linden, H. \& Linden, S. (2017). Fans and fan cultures. New York: Palgrave Macmillan.

Longhurst, B. (2007). Cultural change and ordinary life. Maidenhead: Open University Press.

Lonsway, B. (2009). Making leisure work: Architecture and the experience economy. London: Routledge.

Marini, H. (2013). A performative falling into the cityscape. Performance Research 18(4): 133-142.

Mermikides, A. (2013). Brilliant theatre-making at the national: Devising, collective creation and the director's brand. Studies in Theatre and Performance 33(2): 153-167.

MyTheaterMates.com. (2016, February 12). NEWS: Users launch independent TheatreBoard after closure of WhatsOnStage forum. Retrieved from https:// mytheatremates.com/news-users-launch-independent-theatreboard-after-closureof-whatsonstage-forum/ (20-08-2019).

National Theatre. (n.d.). Online shop. Retrieved from https://shop.nationaltheatre. org.uk (20-08-2019).

Ockman, J. \& Frausto, S. (eds.). (2005). Architourism. London: Prestel.

Open House London. (2019). National Theatre 2019 programme. Retrieved from https://openhouselondon.open-city.org.uk/listings/1172 (20-08-2019).

Reijnders, S. (2011). Places of the imagination: Media, tourism, culture. Farnham: Ashgate.

Rosenthal, D. (2013). The National Theatre story. London: Oberon Books.

Sandvoss, C. (2014). I <3 Ibiza: Music, place and belonging. In: M. Duffett (ed.), Popular music fandom, pp. 115-145. London: Routledge.

Seamon, D. (1979). A geography of the lifeworld: Movement, rest, and encounter. London: Croom Helm. 
Sklair, L. (2017). The icon project: Architecture, cities, and capitalist globalization. Oxford: Oxford University Press.

Tompkins, S. \& Todd, A. (2007). The unfinished theatre. Retrieved from www.studioandrewtodd.com/repository/publications/pdf/The-Unfinished-The-d89ae0e8.pdf (20-08-2019).

Trueman, M. (2016, July 18). Matt Trueman: Theatre rarely lets us be fans. What's On Stage. Retrieved from www.whatsonstage.com/london-theatre/news/matttrueman-theatre-latitude-festival-fans_41309.html (20-08-2019).

Tuan, Y. (1977). Space and place: The perspective of experience. Minneapolis: University of Minnesota Press.

Tulloch, J. (2018). Class 'then' and class 'now'. In: Hotel cerise. In: M.A. Click \& S. Scott (eds.), The Routledge companion to media fandom, pp. 416-427. London: Routledge.

Waysdorf, A. \& Reijnders, S. (2018). Fan homecoming: Analyzing the role of place in long-term fandom of the Prisoner. Popular Communication (online): 1-16.

Williams, R. (2018). Fan tourism and pilgrimage. In: M.A. Click \& S. Scott (eds.), The Routledge companion to media fandom, pp. 98-106. London: Routledge.

Zittoun, T. \& Rosenstein, A. (2018). Theater and imagination to (Re)discover reality. In: T. Zittoun \& V.P. Glaveanu (eds.), Handbook of imagination and culture, pp. 223-242. Oxford: Oxford University Press. 